\title{
A Race to the bottom - Prison Education and the English and Welsh Policy Context
}

[Name of author deleted to maintain integrity of the review process]

[Name of institution deleted to maintain integrity of the review process]

\begin{abstract}
This article examines prison education in England and Wales arguing that a disjuncture exists between the policy rhetoric of entitlement to education in prison at the European level and the playing out of that entitlement in English and Welsh prisons. Caught between conflicting discourses around a need to combat recidivism and a need for incarceration, prison education in England exists within a policy context informed, in part, by an international human rights agenda on the one hand and global recession, financial cutbacks, and a moral panic about crime on the other. The European Commission has highlighted a number of challenges facing prison education in Europe including over-crowded institutions, increasing diversity in prison populations, the need to keep pace with pedagogical changes in mainstream education and the adoption of new technologies for learning (Hawley et al., 2013). These are challenges confronting all policy makers involved in prison education in England and Wales in a policy context that is messy, contradictory and fiercely contested. The article argues that this policy context, exacerbated by socio-economic discourses around neo-liberalism, is leading to a race-to-the-bottom in the standards of educational provision for prisoners in England and Wales.
\end{abstract}

Keywords: Prison education; recidivism; rights; social justice; educational policy; wicked policy

\section{Introduction}

At first glance, the policy texts and rhetoric associated with European legislation on prison education appear enlightened and are expressed in terms of the right to education and training for all learners, regardless of their status. However while legislation, policy documentation and the aspirations of individual member states may argue for a right to education and training, such rights are not always enacted. One recent report from the European Commission noted that 15 countries in Europe, including those of the United Kingdom, reported less than a quarter of all prisoners participating in some sort of education or training (Hawley et al., 2013: 13). Conflict and disjuncture exists between the policy aspirations at a European level and the ways in which, at a national level, socio-economic pressures can impinge on those policies. This article focuses on the policy context in England and Wales. England is unique, in Europe, for two reasons: first its prison system is widely recognised as being the most privatised in Europe ${ }^{i}$ (Mason 2013; Prison Reform Trust 2013; Howard League 2014) and second, along with Scotland and Wales, it boasts the highest rates of imprisonment in Western Europe (MoJ 2013c; Grimwood and Berman 2012). This article starts by setting out the socio-economic context that has influenced recent prison education policy formation in England and Wales. This discussion is followed by an overview of European prison education initiatives associated with and informed by a human 
rights agenda before looking, more closely, at two aspects of a neo-liberal approach to the provision of education in prisons, namely competitive tendering and funding-by-results. This article examines what these policies mean for English and Welsh prison educationalists and the quality of educational provision for prisoners.

\section{Prison Education - an enduring messiness}

Recent statistics indicate that prison populations are increasing globally with an estimated 10.2 million people incarcerated worldwide, a rise of just over 1 million people in five years (UN, 2009: 11; Walmsley 2013). This global rise is mirrored in figures for prisoners in English and Welsh prisons growing from 75, 320 in 2009 to 84,305 in 2013 (Walmsley 2009; Prison Reform Trust 2014). These figures are significant for all prison education stakeholders for two reasons. First, at a time when many countries face austerity cuts, keeping people in prisons is expensive. Ministry of Justice figures reveal that the average cost of a prison place in England and Wales in $2012 / 13$ was $€ 36,808$ (MoJ 2013b). Yet despite (or in spite of) this high expenditure, two thirds of released adult male prisoners in England are reconvicted within two years (Pike \& Adams 2012), with the European Commission estimating the financial cost of recidivism in England and Wales at some 71 billion Euros (Hawley et al., 2013).

Second, there is evidence that suggests that education in prisons can play some part in reducing reoffending (Social Exclusion Unit 2002). It is true that evidence of an incontrovertible relationship between educational provision in prisons and rates of recidivism remains problematic. One reason for this being the difficulty involved in tracking research participants in this field over longer periods of time in order to establish any link between between these two factors. That said, many studies, particularly from the USA offer evidence of some relationship (see, for example, Steurer et al., 2001; Grafham and Hardcastle 2007). For example, findings from one of the largest-ever meta-analysis of prison education studies ${ }^{\mathrm{ii}}$ carried out in America (Davis et al., 2013) and sponsored by the US Department of Justice, found that inmates who participated in prison education programs had 43 percent lower odds of returning to prison than those who did not. Similarly a recent government funded study in England and Wales of 3085 prisonersiii has shown that reoffending rates decreased by approximately two fifths, when prisoners took part in distance learning programmes. A wide range of academic and vocational courses was included in this study, from the Open University and the Department of Business Innovation and Skills (MoJ 2013c). Nevertheless while evidence would seem to indicate that if people in prisons receive education there is a subsequent reduction in their recidivism, it is difficult to conclusively claim that it is their education in prison that is responsible for this reduction as it could be that other factors are involved such as increased maturity or post-prison opportunities. Those that volunteer to take part in prison education may also be more motivated to 'go straight' than those that do not making it difficult to ascertain the extent to which education itself is the key factor in reducing recidivism.

However, even if conclusive proof were to emerge of a causal link between prison education and a reduction in reoffending, the policy context would still be bedevilled with a wide range of contextualised problems. Briefly, there are practical problems related to infrastructure and the occupational setting of prison education. There are divergent pressures within the system itself. There are also conflicting intepretations about the purpose of prisons and the goals of 
imprisonment. Some of these tensions and conflicts are long-standing, others are more recent. For instance, the Ministry of Justice (MoJ) has acknowledged that 60 of the 124 prisons in England and Wales are overcrowded (MoJ, 2013). Dissatisfaction with the current prison system's infrastructure has been noted by one leading UK think tank, the Policy Exchange, who claim that the system has "grown piecemeal over the last 150 years and comprises purpose built facilities from the age of the Victorian penitentiary, former military bases, country houses [and] poorly built facilities from the 1960s and 70s" (Lokyer 2013: 9). It is worth noting that while New Labour's $£ 55$ billion Building Schools for the Future (DfES 2003) scheme replaced many old Victorian schools with new buildings, no similar programme has ever been put in place for Prisons despite the overcrowded and impoverished conditions that so many prisoners experience. The Prison Reform Trust also notes that none of the recent inspections of the quality of educational provision in 24 prisons by the government's English inspectorate for education, Ofsted, culminated in an 'outstanding' assessment and 15 were rated no better than 'satisfactory' (Hewson 2013). Added to this is evidence, based on a questionnaire completed by 278 prison educators working in England, indicating that the prison teaching workforce is, in many cases, disaffected, disgruntled and demoralised by professional insecurity, coupled with a lack of status and autonomy (Rogers et al., 2014). The reasons for this professional insecurity will be examined later in this article.

Turning to divergencies in the purposes of prisons held by various stakeholders, attempts to engage with issues around the efficacy of prison education are fraught with difficulty and are characterised by competing expectations. Societal expectations that prisons fulfil the separate, often contested, goals of punishment, incapacitation, deterrence and rehabilitation collide with evidence, at an international level, that educational provision may, under the right circumstances, lessen rates of recidivism (Davis et al., 2013). Constrained by shrinking budgets, many prison governors however, have to weigh up the extent to which particular activities (including those related to education) in prison are affordable and can meet the sometimes competing and conflicting expectations of individual prisoners, those of their victims, those reflected in prison objectives and those determined by governmental policy. For many politicians a problem exists in balancing a desire to bring about societal change for the better, and the political expediency necessary to ensure success at the ballot box. Attempts at reforming education in prisons are likely to be viewed by many voters as controversial with some seeing prison as simply a deterrent while others focusing on how prison can play its part in the overall humanitarian reform of the prisoner. Of course while there may be come dissonance over the purpose of imprisonment, there is little evidence to suggest that the public holds strong views about the merits or not of prison education as this matter is rarely discussed in the literature. However when it comes to the way in which the popular media reports crime, law-breaking and offending, the situation is very different. Competing expectations and the dilemmas associated with them are exacerbated within the English context by a tabloid media disproportionately constructing and demonising lawbreaking as violent, sub-human or parasitic. The English mass media's long-standing capacity to ferment fears about criminals, crime and disorder is well documented (Cohen 1972; Hall et al., 1978; Philo 1990; Davis et al., 2013) with some commentators pointing out how news and fiction concentrate overwhelmingly (and disproportionately) on serious violent crimes (Reiner 2002). Not surprisingly, some policy debates have increasingly focused on the fear of crime as an issue potentially as serious as any crime itself (Ditton and Farrell 2000). This fear of crime and of the 'penal populism' (Beckett 1997) it generates, i.e. the competition between major political parties to be 'tough on crime' is worrying. It can exacerbate existing public fear over the potential 
rehabilitation of prisoners and lead to ever increasingly repressive policy solutions (Greer et al., 2012; McNulty et al., 2014). These constructions endorse an anthropology of low expectations around the rehabilitative potential of the prison system and convey a version of prison-education as permissive and counterproductive do-gooding. Indeed, the United Nations General Assembly noted that:

The all too ready willingness of politicians to reflect these fears in penal policy has led to a reluctance to embed prisoners' rights to education and to develop models of education and delivery consistent with the full development of the human personality (Munoz 2009: 11)

However while the news of politicians and the public have always influenced policy outcomes for prison provision and prison education, these views have changed over time. Currently in England and Wales there is perhaps more concern with 'education' and 'rehabilitation' in terms of reducing re-offending by getting ex-prisoners into work. This is evidenced in the 'Transforming Rehabilitation' document published by the MoJ (2013a).

\section{A European 'Right' to Prison Education}

It is not the place here to argue the extent to which political, civil, cultural, economic and social rights are a product of 'natural law' or a means by which certain behaviours can be normalized and/or codified. These arguments have been well rehearsed, as have those that attribute human rights, including the right to education, to either morally relativist or universalist philosophical standpoints (see: Ishay 2004; Beitz 2009; Starkey 2012). It is however the place to point out that while many international organisations promote the right to education as a universal entitlement, this right is, within the context of prison education, contested, far from absolute, and subject to limitation. With less than 25\% of prisonersiv (Hawley et al., 2013: 13) receiving some sort of formalised education or training in so many European countries it is hard to realise in practice the right all prisoners have to formalised education and training in practice. It is enshrined in the United Nations General Assembly policy documentation that "all prisoners should have the right to take part in cultural activities and education aimed at the full development of the human personality" (UN, 2009: 9). Significant legislation emanating from the European Union exists to ensure that this right includes the marginalised, the dispossessed and the incarcerated, the latter representing approximately 640,000 of the Union's population (Hawley et al., 2013: 12). Article 2 of the First Protocol to the European Convention on Human Rights decrees that "no person shall be denied the right to education" (Council of Europe 1950). Similarly Article 14 of the Charter of Fundamental Rights of the European Union states that "Everyone has the right to education and to have access to vocational and continuing training" (European Council. 2000: C364/11). However despite all this policy rhetoric of the rights to an education, the Equality and Human Rights Commission has been critical of the way in which this right has been expressed.

... this [right] is expressed in negative rather than positive terms, reflecting the comparatively weak protection it provides. It requires every signatory to guarantee that individuals can take advantage of existing educational institutions, but it does not guarantee an education of a particular kind or quality, or that the education will be provided by a particular institution (Human Rights Review. 2012: 425) 
Similarly, the Council of Europe's European Prison Rules (2006) states that, as far as practicable, the education of prisoners shall:

be integrated with the educational and vocational training system of the country so that after their release they may continue their education and vocational training without difficulty [article 28.1]

Yet, prison education has been surprisingly invisible in some European policy documentation. The European Commission's 2001 Commission on Lifelong Learning (EC 2001), for example, made no reference whatsoever to prisons, prisoners and their educators. Much of the literature coming from the European Union on adult learning tends to homogenise adult education and training needs for the marginalised. For example, while the European Council's (2011) Council Resolution on a Renewed European Agenda for Adult Learning explicitly addresses those traditionally excluded from learning it is noteworthy that prisoners are referred to just once in this document. Other reports commissioned by the European Commission, explicitly addressing prison education, can at times convey naivety regarding policy implementation and practice within a secure institution. For example, while the "development and implementation of tools and schemes to enhance the transferability of qualifications and recognition of skills" may be "particularly relevant to education and training in prisons" (Hawley et al., 2013: 16) its quality is contingent on the efficiency and efficacy of the prison educational system in question. This would include the degree to which the prison educational workforce has been trained to educate within these very specialised environments. 'Right' and 'access' are not coterminous. The 'considerable barriers' that prisoners potentially face accessing education provision become more apparent when we look at the policy context of England and Wales.

\section{Prison education policy in England and Wales.}

The prevailing neo-liberal policy framework, characteristic of the public sector in general and education in particular (Harvey 2005; Wacquant 2010; Tombs 2015), provides the canvas onto which prison education policy is projected in England and Wales. It is a depiction characterised by both endogenous and exogenous forms of privatisation (Ball and Youdell 2007). The former, associated with the importation of ideas and practices borrowed from the private sector (e.g. performance related pay; short term contracts), the latter involving the opening up of public services to the competitive participation of the private sector. Endogenous and exogenous forms of privatisation inform two aspects of English prison policy that will be explored in this paper, namely, competitive tendering and funding by results. Both aspects are responsible for a gap, a disjuncture, between the policy rhetoric of entitlement to education and its realisation in practice in English prisons.

The practice of competitive tendering has been a feature of educational provision in England for over two decades, grounded in the belief that the competitive 'market' is the antidote to the perceived failings of Keynesianism in more efficiently allocating human and material resources (Dunn 2009). Formally facilitated through local education authorities (local councils in England and Wales responsible for education within their jurisdiction) and by prison instructors employed directly by HM Prison Service, prison education has, since 1993 been contracted out in various guises to external providers including colleges of Further Education (FE), Local Authorities (LA) and private companies. In 2003 two agencies, the Learning Skills Councilv (LSC) 
and the National Probation Servicevi, funded the creation of the Offenders' Learning and Skills Service (OLASS). The aim of OLASS was to create and sustain a single integrated service for prisoners that, according to the Department for Innovation, Universities and Skills, would ensure that offenders had:

the underpinning skills for life (literacy, language, numeracy and basic IT skills), and have developed work skills [enabling] them to meet the real needs of employers in the area where they live or will settle after their sentence is complete (DfIUS 2007: 2).

While OLASS was not without its critics (see Halsey et al., 2006 vii) who raised concerns about its capacity to meet the needs of a diverse set of prisoners, it was regarded as an improvement on previous attempts to reform the delivery of education in prisons (House of Commons 2008; Natale L. 2010). O'Brien (2010: 29) notes, for example, that "offender participation in OLASS provision rose from 30 to 36 per cent in its first year of operation". However, a change in government in the UK in 2010 brought with it plans for more reform of the criminal justice system and educational provision in prisons and in its 2011 governmental review Making Prisons Work, the Ministerial Foreword stated that:

Whilst we have increased prisoner participation in learning and skills, the system is not performing well, as repeatedly confirmed in many reports from the Independent Monitoring Boards and the Prison Inspectorate. Recent reports from Ofsted confirm this. Directors of learning and skills in prisons have been immensely frustrated at being unable to make the best of resources available due to inflexibilities of the system they are presented with (Department for Business Innovation and Skills \& the Ministry of Justice. 2011. p.3, my italics)).

These inflexibilities are well documented (Bracken 2011; Pike 2012; Rogers et al., 2014) and include, for example, the frequent transfer of prisoners between institutions; a narrow curriculum focussing on basic or 'employability' skills; limited or non-existent Internet access for many prisoners; chronic staff shortages; and an over emphasis on security and efficiency to the detriment of education and training (e.g. limiting what resources can be brought into prison learning environments). Within the context of a commitment to reduce re-offending Making Prisoners Work included a renewed focus on making prisons a preparation for work. Thus there was an emphasis on greater provision of vocational skills training in the twelve months immediately before release. Indeed, eligibility for education and training was contingent on prisoners being within a certain proximity to release. This process was managed by the joint procurement, between the Skills Agency and the Ministry of Justice's National Offender Management Service (NOMS), of educational provision with new contracts to start in 2012 (NOMS 2013).

One immediate outcome of this review was a governmental document (Skills Funding Agency 2012) setting out the agreed arrangements for delivery of the Offenders' Learning and Skills Service Phase 4. 'OLASS 4' brought with it a range of contracts for the delivery of learning and

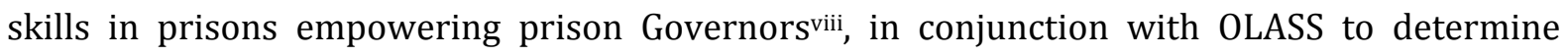
prisoner educational provision. Contracts are awarded to Further Education (FE) colleges and private organisations on the basis of three-yearly competitive tendering. This means that educational providers competitively bid to manage educational departments in prisons with, in many cases, inevitable changes in the management and employment conditions for teachers and, 
with what has been acknowledged, as a lack of continuity, consistency and quality in educational provision for prisoners (Champion 2013). Citing one prison educator in their study, Rogers et al., (2014) draw attention to how the instability associated with competitive tendering can impair the prison learning-environment:

Changing employer every three years is not beneficial to a department. It can take up to two years to get properly acquainted and set up smoothly with a new employer. Changing so often is unsettling for staff and does not allow continuity of systems for learners [interviewee cited in Rogers et al., 2014: 36).

OLASS 4 arrangements focus on funding by results. Educational providers must draw down money that is outcomes-driven and employability-focused. The OLASS Funding Rules and Guidance notes state the need for:

a revision of funding to bring allocations for each prison in line with new priorities including funding based on outcomes (enrolments, achievements, success rates and progression) [The Skills Funding Agency. 2013: p.3].

This revision reconstructs prison education as training by limiting the extent to which prisoners can choose to be involved in higher level and/or longer term educational pathways. For example, the Guidance notes state that:

From 1 August 2013, any learner who is aged 24 or over at the start of learning and is studying any of the learning aims or Apprenticeship frameworks listed below will not be eligible for funding through OLASS, but may apply for a Loan.

- Qualifications and Credit Framework (QCF) Certificates and Diplomas at levels 3 and 4 ix

- Programme of A-levels (including AS, A2 and full A-levels)

- Quality Assurance Agency (QAA) Access to HE Diplomas

- Advanced-level Apprenticeship framework Higher Apprenticeship framework" [The Skills Funding Agency. 2013: p.3].

Level 3 (vocational) courses and A level (academic) programmes are longer-term educational pathways (typically taking two years to complete within mainstream educational provision). These programmes act for many as the bridge between school and university. Earlier in this paper I argued that while EU prisoners have the right to an education, in practice it can be hard to access. OLASS 4 provides some access but it comes hedged by caveats and conditions. For example, while the funding system relying on loans affects all people over the age of 24 and not just prisoners the OLASS Guidance notes appear to disincentivise prisoner aspiration and demand for higher-level courses while incentivising the supply of short vocational and skills-based educational pathways from educational providers. For example, addressing educational providers, the Guidance notes state that:

By September 2013 [educational providers] must provide a delivery plan, which sets out a core curriculum made up from three elements:

- English and maths and ESOL;

- vocational qualifications, including information and communications technology (ICT); and

- employability skills (these may include a wide range of team-working, personal, social and other skills) [The Skills Funding Agency. 2013: 6]. 
Beyond the obvious difficulties that many prisoners will face in applying for, and being granted, loans, this mandated guidance seems to suggest a policy focus on short-term and narrowly economistically "hard" instrumental outputs. Rogers et al., (2014) drawing on their survey data found that nearly two-thirds (62\%) of prison educators in their study criticised competitive tendering for prison contracts and the fact that funding is dependant on prisoners' results. They argued that a payment-by-results model "rewards providers who maximise revenue by providing short, low level courses that typically secure high success and completion rates" (ibid. 39). Similarly, Champion (2013), in a report commissioned by the Prisoners' Education Trust notes that "although in theory paying by the number of qualifications achieved sounds sensible, in reality, it can lead to perverse outcomes and a 'bums on seats' or 'tick box' culture" (ibid p.17). In the next section of this paper I argue that this short-term instrumental policy focus produces a disjuncture between policies of entitlement to education at the European level and the way in which this entitlement is enacted in practice in English and Welsh prisons.

\section{The disjuncture between an educational right and its realisation}

The (re)construction of English and Welsh prison education, increasingly into short, low level courses seems a long cry from the United Nations (UN) policy documentation that argues that prison education:

...should be aimed at the full development of the whole person requiring, among other things, prisoner access to formal and informal education, literacy programmes, basic education, vocational training, creative religious and cultural activities, physical education and sport, social education, higher education and library facilities (Munoz 2009: 7)

There is evidence to suggest that a gap exists, at the European level, between these aims and the extent to which prisoners access education in this broader sense. One recent survey (Hawley et al., 2012), distributed to national coordinators of prison education in 35 countries in Europe, identified two sets of barriers to education experienced by many prisoners. The first set, dispositional barriers, include the "effects of a disadvantaged childhood, previous educational failure and low self-esteem, of drug and alcohol abuse, and communication learning and mentalhealth disabilities" (Munoz 2009: 11). These 'effects' are characteristic of the profile of much of the prison population in England and Wales (Costelloe and Lengelid 2011; Hurry et al., 2012). For example, prisoners in England and Wales are "13 times as likely to have been in care as a child, 13 times as likely to be unemployed, 10 times as likely to have been a regular truant, [and] 2.5 times as likely to have had a family member convicted of a criminal offence" (Bracken 2011: 7). It is hardly surprising then that a "lack of motivation to learn" and "previous negative experiences of education" are the most commonly reported reasons why many English and Welsh prisoners do not engage in prison education and training in the first place, even where it is provided (Hawley et al., 2012: 61).

The second set of barriers, experienced by many prisoners in England and Wales, are associated with institutional and situational factors and compound any dispositional barriers. These factors include the interruption of learning brought about by movement from one prison to the next due to overcrowding in some prisons; limited availability of places for learners (e.g. classroom space; ratio of learners to teachers); a limited curriculum offer of education and training in terms of both 
the level and content and a shortage of human and material teaching and learning resources (e.g. appropriately qualified staff and the availability of computer facilities) (Munoz, 2009). All these factors are evident in the English and Welsh prison system despite the arrival of OLASS. In a paper commissioned for the House of Commons (Garton Grimwood and Berman 2012) it was noted that the overcrowding of prisons and the subsequent strategy of movement of prisoners from one prison to the next not only disrupts any attempt at their formative assessment but also their opportunities to stay on any one particular course they apply for. The research also identified a lack of classroom and workshop space, and limited quiet study areas in many prisons hampering the quality of educational provision. This finding has been endorsed by the latest Annual Report from HM Chief Inspector of Prisons in England and Wales which noted that "too many prisons lacked sufficient activity places to ensure all prisoners had good access to education or vocational training" (HM Chief Inspector of Prisons 2014: 43).

Shortly after the Department for Education and Skills (DfES) had taken over responsibility for prison education, the Education and Skills Committee, in 2005, noted that:

An over emphasis on basic skills driven by Key Performance Targets has narrowed the curriculum too far. Whilst aiming to meet the basic needs of prisoners the Government must endeavour to broaden out the prison education curriculum and increase flexibility of provision to meet the much wider range of educational needs that exists within the prison system (Education and Skills Committee Prison Education 31 ${ }^{\text {st }}$ March 2005, HC825 2004-05: 61-62).

Nine years later, little seems to have changed as was evident in the (2014) Annual Report from HM Chief Inspector of Prisons:

The range of learning provision offered too few opportunities for prisoners to progress... Courses were not always accredited at a high enough level, with many providing only a level 1 qualification. As a result some [prisoners] took courses to gain qualifications that were too low a level and not sufficiently challenging (HM Chief Inspector of Prisons 2014: 45)

Findings from a survey of 343 prisoners carried out in 2014 by the Prisoners Education Trust support the findings of the Annual Report arguing that: "the current system is more suitable for short sentences; offering bite-size, low level courses and not explicitly funding distance learning support" (Taylor 2014: 4). Higher Education (HE) courses do exist in English and Welsh prisons and are considered to be potentially transformative for prisoners (Duguid and Pawson 1998; Wilson and Reuss 2000; Pike and Adams 2012). However while access to these courses is more widely available and more easily embedded in high security prisons with long-term prison populations, those prisoners who are coming towards the end of their sentences (and therefore have been moved into lower level category prisons) will, in many cases, no longer have access to these longer (and more costly) educational courses. Most HE provision takes the form of on-line distance learning courses (e.g. those provided by the Open University). Despite the fact that OLASS has invested in the upgrading and replacement of ICT in many prisons (Pike and Adams 2012) the technology-enhanced learning associated with these courses is being undermined by a payment-by-results emphasis on short term, employability-focused courses in the majority of prisons. 
A UK-wide review of prison educators in 2009 suggested that many teachers working in prisons lacked appropriate knowledge and understanding of the skills and practices required to work in this challenging environment (Centre for Social Justice 2009). This deficiency in the skills and practices of prison teaching has also been highlighted in the HM Chief Inspector's 2013-14 report that stated:

Outstanding teaching and learning were rare, even in the better prisons. We were particularly concerned that English and Mathematics were not sufficiently prioritised, with weak teaching reflected in poor achievement in accredited qualifications in most prisons (HM Chief Inspector of Prisons 2014: 45)

Little provision for high quality Continuing Professional Development (CPD) is available for teachers who work in prisons, and the value placed on what CPD is provided by those who experience it varies considerably. In their survey of prison educators Rogers et al., (2014), commenting on the quality of CPD for prison educators noted that:

...the quality of the provision was criticised by $50.7 \%$ of the respondents, even though $64 \%$ reported that the training received over the last 18 months had been relevant to their role, but not the subjects taught (Rogers et al., 2014: 5).

Those respondents that had undergone initial teacher education (ITE) indicated that their courses had not covered the specific needs of prison education. The research also indicated that in most cases the availability of Continuing Professional Development (CPD) for subject expertise and teaching methodology was non-existent (Rogers et al., 2014: 5).

\section{Discussion}

This article has focussed on the policy context in England and Wales surrounding the provision of prison education. It draws attention to the challenges and practices confronting policy makers involved in prison education and to the barriers commonly experienced by prisoners, regardless of where they are held. Some of these challenges are relatively recent and echo across the public sector as a whole (e.g. the endogenous and exogenous forms of privatisation discussed in this paper accompanied by governmental austerity measures). Other challenges are more longstanding and specific to prison education (e.g. an underdeveloped prison infrastructure; an overcrowded and often mobile prison population; negative public opinion of offenders accompanied by negative media attention). A disjuncture exists between the discourses and legislation surrounding the rights of all prisoners to education in Europe and what is happening on the ground in English and Welsh prisons. While there is a rhetoric of inclusion, entitlements and a rights-based approach towards the provision of education and training in the prison services of Europe, in practice in England and Wales, other more dominant policies undercut and marginalise these more humane approaches. A neo-liberal logic that alleges that competitive tendering and performance outcomes are the best drivers to improve prison education has culminated in a race-to-the-bottom in the standards of educational provision for prisoners. In England and Wales, the HM Chief Inspector of Prisons found, in 2013, that both "the quantity and quality of purposeful activity in which prisoners are engaged [has] plummeted" (HM Chief Inspector of Schools of Prisons 2013: 10). The Prison Reform Trust (2014) also signals a deterioration in prisoner performance. Indeed what is documented is the worst outcomes in six 
years with over half of all prisons judged to be not 'sufficiently good' or 'poor' in terms of education provision (Prison Education Trust 2014: 7). With competing government departmental interests in the provision of education in prisons ${ }^{\mathrm{x}}$ it is difficult to see how this policy environment can effectively provide long-term high quality education that prisoners not only need but have an entitlement to.

Prison education is a wicked policy problem (Allen 2004). Wicked policy problems are complex, not fully understood by policy makers, highly resistant to change and seemingly immune to any evidence that is likely to bring about institutional reconstruction. Policy, in the case of prison education, is not driven by what works and is not evidenced-based. It is positioned by political expediency and the signalling of politicians 'toughness on crime' in different ways, in different times. Both resonate with elements in the media that construct prison as a site of punishment rather than a place for reform. This problem is exacerbated further by the perceived cost of prison education provision to the taxpayer. A neo-liberal policy approach of competitive tendering aims to reduce these costs to the state while indirectly reneging on the responsibility to deal with this provision more fully in the ways suggested by European legislation. The reconstruction of prison 'education' into low-cost job skills training contributes to the domination of policies that speak more to public moral panic and the need to cut the economic costs of welfare than to the rehabilitation of prisoners. Somewhat paradoxically, evidence discussed in this article (Davis et al., 2013; MoJ 2013c) is still suggesting the cost-effectiveness of prison education in reducing recidivism.

Prisons can play a significant role in enacting European policy surrounding prisoners' rights to education. They can contribute to the rehabilitation of prisoners by encouraging them to engage in meaningful educational experiences that are not just limited to those associated with 'employability'. The facilitation of this wider curriculum can come from a profession of prison educators resourced, trained and embraced not just by leading practitioners within the field but also by a wider educational community of teachers, teacher educators, researchers, publishers and policy makers. However in England barriers to high quality education exist for most prisoners and are compounded by fragmentation and differentiation. Provision varies depending on the length of incarceration, the type of crime, the type of provider and the location of the prisoner. Those on remand or receiving hospital care receive little or no access to any form of prison education whatsoever. Prison education is facilitated by a 'Cinderella' profession isolated from the professional recognition, accreditation and remuneration of the wider teaching profession. The characteristic ambiguity in England about what constitutes 'education' or 'training' is one that is exacerbated by economism and political sensitivity to penal populism. Such ambiguity provides a space into which the restructuring of prison education risks being determined by discourses associated with punishment and retribution, rather than rehabilitation.

\section{Notes}

\footnotetext{
i 14 prisons are currently run by private companies on behalf of the state, equivalent to 15.3 per cent of the UK prison population (Howard League. 2014). Since 1993 successful contractors have included G4S, Serco, and Sodexo.

ii In this meta-analysis 18 studies were examined by the authors and classified into six categories: Corrective Reading, computer-assisted instruction, personalized instruction, other remedial education, vocational education, and GED (General Education Development) completion.

iii A sample of 3,085 prisoners with access to study showed 19\% had reoffended within a year of release, compared with $26 \%$ of 3,000 similar inmates without this access. The sample was made up of $31 \%$ of prisoners whose custodial sentences ranged from 12 months to less than 4 years; $61 \%$ from 4 to 10 years and $7 \%$ whose sentences were 10 years or more.
} 


\footnotetext{
iv This 20-country survey on Prison Education and Training in Europe can be found at: http://ec.europa.eu/education/adult/doc/survey/survey en.pdf. 15 out of 20 countries (including CY, FI, GR, HU, NL, PL, SK, UK-Scotland \& UK-Wales) reported below $25 \%$ prisoners participate in education and training. However a notable exception was Germany, where between a half and three quarters of their prison population participate in some form of education and training provision.

$v$ The Learning and Skills Council (LSC) was an organisation at the time responsible for funding and planning education and training for over 16 year olds in England. The LSC has now been replaced by the Skills Funding Agency.

vi Established in 2014 the National Probation Service (NPS) is a statutory criminal justice service that supervises high-risk offenders released into the community. In 2003 the NPS was the whole probation service and dealt with all offenders.

vii In their report, commissioned by the Department for Education and Skills, the authors noted that educational provision for some learners fell short of their expectations and that, since the arrival of OLASS, education in the community had not significantly increased for prisoners on probation.

viii Prison governors are responsible for the management and security of prisons, remand centres and young offenders' institutions.

${ }^{i x}$ The QCF provides a categorisation of nine levels of learning that exist in secondary, further, vocational education and higher education. Level 1 qualifications recognise basic knowledge and skills and the ability to apply learning with guidance or supervision. Level 8 courses are generally considered to be of Doctoral equivalency.

${ }^{x}$ The Ministry of Justice, the Treasury, the Department for Education, the Department for Business Innovation and Skills, and the Home Office.
}

\section{References}

Allen, J. 2004. Sociology of Education (3 ${ }^{\text {rd }}$ Edition). Southbank Victoria: Social Science Press, Thomson Learning Australia.

Ball, S.J., and D. Youdell. 2007. Hidden Privatisation in Public Education. Preliminary Report prepared for Education International 5th World Conference July 2007.

Beckett, K. 1997. Making Crime Pay: Law and Order in Contemporary American Politics. New York: Oxford University Press.

Beitz, C. R. 2009. The idea of human rights. Oxford: Oxford University Press

Bracken, C. 2011. Bars to Learning: Practical Challenges to the working prison. London: CIVITAS

Braggins, J., and J. Talbot. 2003. Time to Learn: Prisoners' views on prison education. London: Prison Reform Trust.

Bowring, B. 2012. Human Rights and Public Education. In: Cambridge Journal of Education 42, no. 1: 53-65

Centre for Social Justice. 2009. Breakthrough Britain: Locked Up Potential - A strategy for reforming prisons and rehabilitating prisoners.

http://www.centreforsocialjustice.org.uk/UserStorage/pdf/Pdf\%20reports/CSJLockedUpPoten tial.pdf

Champion, N. 2013. Smart Rehabilitation - Learning how to get better outcomes. London: Prisoners' Education Trust.

Cohen, S. 1972. Folk Devils and Moral Panics. London: Paladin 
Costelloe A., and T. Langelid. 2011. Prison Education and Training in Europe - a review and commentary of existing literature, analysis and evaluation. Directorate General for Education and Culture, European Commission (GHK).

Council of Europe. 1950. The European Convention on Human Rights. Rome 4 1950. Five Protocols. http://www.hri.org/docs/ECHR50.html\#P1.Art2

Council of Europe. 2006. Recommendation Rec (2006)2 of the Committee of Ministers to member states on the European Prison Rules (adopted by the Committee of Ministers on $11^{\text {th }}$ January 2006 at the $952^{\text {nd }}$ meeting of the Ministers' Deputies).

https://wcd.coe.int/ViewDoc.jsp?id=955747

Davies, P., P. Francis and C. Greer. 2013. Victims, Crime and Society. London: Sage.

Davis, L.M., R. Bozick., J.L. Steele., J. Saunders., and J.N.V. Miles J.N.V. 2013. Evaluating the Effectiveness of Correctional Education: A Meta-Analysis of Programs That Provide Education to Incarcerated. Washington: Bureau of Justice Assistance: US Department of Justice.

Department for Education and Skills. 2003. Building Schools for the future: Consultation on a new approach to Capital Investment. Nottinghamshire: DfES Publications.

Department for Business, Innovation and Skills \& Ministry of Justice. 2011. Making Prisons Work: Skills for rehabilitation: Review of Offender Learning. London: Ministry of Justice

Department for Innovation, Universities and Skills. 2007. The Offenders' Learning and Skills Service (OLASS) in England: a brief guide. London: DfIUS.

Ditton, J., and S. Farrall. (eds) 2000. The Fear of Crime. Aldershot: Dartmouth.

Duguid, S., and R. Pawson. 1998. Education, change and transformation: the prison experience. Evaluation Review 22: 470-495.

Dunn, B. 2009. Global Political Economy - a Marxist critique. London: Pluto Press.

Education and Skills Committee Prison Education 31st March 2005, HC825 2004-05: 61-62.

European Convention on Human Rights, Council of Europe, Strasbourg. http://www.echr.coe.int/Documents/Convention_ENG.pdf

Equality and Human Rights Commission. 2012. Human Rights Review 2012 - How fair is Britain?An assessment of how well public authorities protect human rights. London: Equality and Human Rights Commission.

http://www.equalityhumanrights.com/uploaded files/humanrights/hrr firstprotocol.pdf

European Council. 2011. Council Resolution on a renewed European agenda for adult learning. 2011. Doc. 2011/C 372/01. The Official Journal of the European Union. http://csdle.lex.unict.it/Archive/LW/EU\%20social\%20law/EU\%20nonbinding\%20acts/Opinions\%20and\%20resolutions/20111220$\underline{025542111220 \text { Council adult learning enpdf.pdf }}$

European Council. 2000. Charter of Fundamental Rights of the European Union. Official Journal of the European Union Communities. http://www.europarl.europa.eu/charter/pdf/text en.pdf 
European Commission. 2001. Communication from the Commission: Making a European Area of Lifelong Learning a reality. Brussels, 21.11.01. COM(2001) 678 final. http://www.bolognaberlin2003.de/pdf/MitteilungEng.pdf

European Council. 2011. Council Resolution on a renewed European agenda for adult learning. 2011. Doc. 2011/C 372/01. The Official Journal of the European Union. http://csdle.lex.unict.it/Archive/LW/EU\%20social\%20law/EU\%20nonbinding\%20acts/Opinions\%20and\%20resolutions/20111220025542_11_12_20_Council_adult_learning_enpdf.pdf

Garton Grimwood, G., and G. Berman. 2012. Reducing Reoffending: the "What works" debate. Research Paper 12/71. London: The House of Commons Library

Greer, C. and R. Reiner. 2012. Mediated mayhem: media, crime, criminal justice In: Maguire, M., R. Morgan, and R. Reiner (eds.) The Oxford Handbook of Criminology. Oxford University Press, Oxford.

Graffam, J., \& L. Hardcastle. 2007. Ex-prisoners and ex-offenders and the employment connection: assistance plus acceptance. In Dawe, S. (ed.) Vocational education and training for adult prisoners and offenders in Australia: research readings. Adelaide: NCVER.

Grimood, G.G., and G. Berman. 2012. Reoffending: The 'What works debate'. The House of Commons: The House of Commons Library

HM Chief Inspector of Prisons. 2014. Annual Report 2013-14. London: Crown Copyright. http://www.justiceinspectorates.gov.uk/hmiprisons/wpcontent/uploads/sites/4/2014/10/HMIP-AR 2013-14.pdf

Halsey, K., K. Martin., and R. White. 2006. The Implementation of OLASS - an assessment of its impact one year on. London: National Foundation for Educational Research.

Hall, S., C. Critchley., T. Jefferson., J. Clarke., and B. Roberts. 1978. Policing the Crisis. London: MacMillan.

Harvey, D. 2005. A Brief History of Neoliberalism. New York: Oxford University Press.

Hawley, J., I. Murphy., and M. Souto-Otero. 2012. Survey on Prison Education and Training in Europe - Final Report. Order 23 of the DG Education and Culture Framework Contract 02/10Lot 1. July 2012.

Hawley, J.. I. Murphy., and M. Souto-Otero. 2013. Prison Education and Training in Europe: Current state-of-play and challenges - a summary report authored for the European Commission. Brussells: GHK publishing.

Hewson, A. 2013. Bromley Briefings Prison Factfile. London: Prison Reform Trust.

House of Commons. 2008. Meeting needs? The Offenders' Learning and Skills Service - The fortyseventh Report of Session 2007-8. London: The House of Commons

Howard League for Penal Affairs. 2013. Weekly Prison Watch: Latest figures - week ended 11th January 2013. http://www.howardleague.org/weekly-prison-watch/ 
Human Rights Review. 2012.

http://www.equalityhumanrights.com/sites/default/files/documents/humanrights/hrr_firstpr otocol.pdf

Hurry, J., L. Rogers., M. Simonot., and A. Wilson. 2012. Inside Education: The Aspirations and Realities of Prison education for under 25s in the London Area - A report for Sir John Cass's Foundation. London: Centre for Education in the Criminal Justice System, Institute of Education, University of London.

Ishay, M. 2004. The history of human rights: From ancient times to the globalization era. Los Angeles, California: University California Press

Lockyer, K. 2013. Future Prisons - A radical plan to reform the prison estate. London: Policy Exchange.

Mason, C. 2013. International Growth Trends in Prison Privatisation. Washington: The Sentencing Project

McNulty, D., N. Watson., and G. Philo. 2014. Human rights and prisoners' rights: the British press and the shaping of public debate. Howard Journal of Criminal Justice.

http://onlinelibrary.wiley.com/doi/10.1111/hojo.12075/abstract

Ministry of Justice and National Offender Management Service. 2012. Delivery of the Offenders' Learning and Skills Service Phase 4 (OLASS 4) 2012/13. London: The Skills Agency

Ministry of Justice. 2013a. Transforming Rehabilitation: A Strategy for Reform. https://consult.justice.gov.uk/digital-communications/transformingrehabilitation/results/transforming-rehabilitation-response.pdf

Ministry of Justice. 2013b. National Offender Management Service Annual Report and Accounts 2012-13. Management Information Addendum. Ministry of Justice Information Release published $17^{\text {th }}$ October 2013.

https://www.gov.uk/government/uploads/system/uploads/attachment_data/file/225225/miaddendum.pdf

Ministry of Justice. 2013c. Justice Data Lab Reoffending Analysis: Prisoners Education Trust. London: Ministry of Justice.

Ministry of Justice. 2013d. Proven Re-offending statistics quarterly bulletin - July 2010 to June 2011, England and Wales.

https://www.gov.uk/government/uploads/system/uploads/attachment_data/file/192631/pro ven-reoffending-jul-10-jun-11.pdf

Munoz, V. 2009. Promotion and protection of human rights, civil, political, economic, social and cultural rights, including the right to development - the right to education of persons in detention. Report of the Special Rapporteur on the right to education. United Nations General Assembly. Dist. General. A/HRC/11/8. 2nd April 2009. http://www2.ohchr.org/english/bodies/hrcouncil/docs/11session/A.HRC.11.8_en.pdf

Natale, L. 2010. Factsheet - Education in Prisons. London: CIVITAS Institute for the study of civil society. 
National Offender Management Service. 2013. The Offenders' Learning and Skills Service Phase 4 (OLASS 4) Governance Guidance Note. London: The Skills Funding Agency

O'Brien, R. 2010. The Learning Prison. London: The Royal Society for the encouragement of Arts, Manufactures and Commerce (RSA).

Philo, G. (ed.) 1990. Seeing and Believing: The Influence of Television. Routledge: London.

Philo, G. 2007. Can Discourse Analysis Successfully Explain the Content of Media and Journalistic Practice. Journalism Studies 8 no. 2: 175-196.

Pike, A. and T. Irwin. 2008. Improving access to higher education and distance learning. In: Fifth EDEN Research Workshop, 20-22 Oct 2008, Paris, France.

Pike, A., and A. Adams. 2012. Digital Exclusion or learning Exclusion? An Ethnographic study of adult male distance learners in English Prisons. Research in Learning Technology 20: 363-376.

Prison Reform Trust. 2013. Prison: The Facts - Bromley Briefings Summer 2013. London: Prison Reform Trust

Prison Reform Trust. 2014. Prison: The Facts - Bromley Briefings Summer 2014. London: Prison Reform Trust

Quinn, A. 2007. Contrary to claims, conventions and culture: An apologia for the Glasgow University Media Group. International Journal of Media \& Cultural Politics 3, no. 1: 5-24.

Reiner, Robert. 2002. Media made criminality: The representation of crime in the mass media. Reiner, R., M. Maguire,and R. Morgan. (eds.) The Oxford Handbook of Criminology. Oxford: Oxford University Press.

Rogers, L., M. Simonot., and A. Nartey. 2014. Prison Educators: Professionalism Against all the odds. London: UCU and IoE.

Sagan, C. 1995. The Demon Haunted World: Science as a candle in the dark. New York: Random House.

Schmitt, M-J. 2008. The Charter of the Fundamental Rights of the European Union - Reading Guide. Brussels: Conference of INGOS of the Council of Europe.

Skills Funding Agency. 2012. Delivery of the Offenders' Learning and Skills Service Phase 4 (OLASS 4) 2012/13. London: Ministry of Justice National Offender Management Service.

The Skills Funding Agency. 2013. Funding Rules and Guidance 2013/14 for the Offenders' Learning and Skills Service (OLASS). London: Skills Funding Agency.

Social Exclusion Unit. 2002. Reducing Re-offending by Ex-prisoners, Office of the Deputy Prime Minister: http://www.thelearningjourney.co.uk/file.2007-10-01.1714894439/file_view Accessed 2 July 2013

Starkey, H. 2012. Human rights, cosmopolitanism and utopias: implications for citizenship education. In: Cambridge Journal of Education 42, no. 1: 21-35 
Steurer, S., L. Smith., and A. Tracy. 2001. OCE/CEA Three State Recidivism study. Correctional Education Association paper.

http://www.acea.org.au/Content/2001\%20papers/Dr\%20Steve\%20Steurer\%20\%20Paper.PDF

Taylor, C. 2014. Brain Cells. Listening to Prisoner Learners. London: Prison Education Trust.

Tombs, S. 2015. Crisis, What Crisis? Regulation and the Academic Orthodoxy. The Howard Journal of Criminal Justice 54. no. 1: 57-72.

United Nations. 2009. Promotion and Protection of Human Rights, Civil, Poltical, Economic, Social and Cultural Rights, including the right to development - the right to education of persons in detention. Human Rights Council, Eleventh Session Agenda item 3: A/HRC/11/8 2nd April 2009. http://www2.ohchr.org/english/bodies/hrcouncil/docs/11session/A.HRC.11.8_en.pdf

Wacquant, L. 2010. Crafting the Neoliberal State: Workfare, Prisonfare and Social Insecurity. Sociological Forum 25. no. 2: 197-220.

Walmsley, R. 2013. World Prison Population List (Tenth Edition). London: International Centre for Prison Studies, King's College London.

Walmsley, R. 2009. World Prison Population List (Sixth Edition). London: International Centre for Prison Studies, King's College London.

Wilson D., and A. Reuss. [eds]. 2000. Prison(er) Education: Stories of Change and Transformation. Waterside Press: Winchester VA.

Wright R. 2005. Going to Teach in Prisons. The Journal of Correctional Education 56, no. 1: 1938. 